\title{
Evaluating the Suitability of Baobab Fruit Shells as Substrate for Growing Oyster Mushroom (Pleurotus ostreatus)
}

\author{
Delight Michael Tavarwisa $\left(\mathbb{D},{ }^{1}\right.$ Chido Govera $\left(\mathbb{D},{ }^{2}\right.$ Moses Mutetwa $\left(\mathbb{D},{ }^{3}\right.$ \\ and Wonder Ngezimana $\mathbb{D}^{1}$ \\ ${ }^{1}$ Marondera University of Agricultural Sciences and Technology, Department of Horticulture, P.O. Box 35, \\ Marondera, Zimbabwe \\ ${ }^{2}$ Future of Hope Foundation, Christon Bank, Mazowe, Zimbabwe \\ ${ }^{3}$ Midlands State University, Faculty of Natural Resource Management and Agriculture, \\ Department of Agronomy and Horticulture, Gweru, Zimbabwe \\ Correspondence should be addressed to Moses Mutetwa; mosleymtetwa@gmail.com
}

Received 16 December 2020; Revised 2 February 2021; Accepted 16 February 2021; Published 28 February 2021

Academic Editor: Isabel Marques

Copyright (C) 2021 Delight Michael Tavarwisa et al. This is an open access article distributed under the Creative Commons Attribution License, which permits unrestricted use, distribution, and reproduction in any medium, provided the original work is properly cited.

\begin{abstract}
The baobab fruit shells were evaluated for their suitability as a substrate for growing oyster mushrooms and compared to three base substrates (wheat straw, maize cobs, and sawdust) of $1 \mathrm{~kg}$ dry weight. The duration of developmental stages, mycelium vigor, yield, and biological efficiency of the oyster mushroom from the four different substrates were recorded. Yields from the first 3 harvests (flushes) were considered, as they were the most productive ones. Wheat straw demonstrated significantly $(p<0.05)$ higher mycelial colonization rate taking an average of 23 days to complete full spawn run followed by baobab fruit shells, sawdust, and maize cobs which took averages of $25.8,27.2$, and 29.5 days, respectively. Baobab fruit shells had the longest number of days taken between full spawn run and first pinhead formation with an average of 14.4 days which was significantly different $(p<0.05)$ to the wheat straw, sawdust, and maize cobs which had 7.4, 9.4, and 10.5 days. The highest yield was observed on the sawdust which had an average of $682 \mathrm{~g}$ followed by wheat straw with $594 \mathrm{~g}$. Maize cobs and baobab fruit shells had the least yield of $518 \mathrm{~g}$ and $482 \mathrm{~g}$, respectively. The results showed that baobab fruit shells could be used as a substrate for the cultivation of oyster mushrooms and it can be recommended for commercial cultivation of oyster mushrooms.
\end{abstract}

\section{Introduction}

Malnutrition is a huge problem in developing third world countries. Oyster mushrooms, with their flavor, texture, nutritional and medicinal value, and high productivity per unit area, have been identified as an excellent food source to alleviate malnutrition in developing countries [1]. Oyster mushrooms are eaten as meat substitutes and flavoring and they can also be processed into various products through value addition. Currently, high biofuel prices have caused an increase in food prices and food scarcity in many countries. Oyster mushroom is unarguably one of the easiest of all mushroom species to grow. It is relatively fast-growing and it can grow on a variety of locally available and cheap substrate materials. To alleviate hunger and malnutrition in a world threatened by climate change and rising food prices, the cultivation of mushrooms is therefore necessary.

The utilization of mushrooms by humans is believed to have originated during the Stone Age era by some anthropologists who suggest mushrooms had a huge influence on the course of human evolution [2]. Although here in Africa, mushroom cultivation is not considered a traditional activity, mushroom collection however is a traditional activity that is usually carried out in the rainy season when they sprout from the Earth's surface. Oyster mushroom, one of the most common edible species, is believed to have been first cultivated in Germany during the First World War. It is one of the most produced mushroom species in the world, 
contributing up to $25 \%$ of the commercially cultivated mushrooms worldwide $[3,4]$. Oyster mushrooms in the wild may be found under different colors such as grey, tan, dark brown, and the yellow oyster mushroom with a wide fan or cap, which may span for about 5 to $25 \mathrm{~cm}$ and white flesh [5].

Mushrooms have, over the past years, gained more popularity worldwide due to their high nutritional and medicinal values, which have led to high demand for both medicinal and gourmet mushrooms [6,7]. Some of the highly demanded, cultivated mushrooms include button mushrooms, oyster, Shiitake, Maitake, and Enoki. The surging use of mushrooms as ingredients in various food products has fueled the mushroom market growth over the years [8].

Mushrooms possess various nutritional properties such as low fat and low cholesterol, and they have also been reported to contain more protein than any other food of plant origin and are also a good source of mineral nutrients $[9,10]$. Additionally, edible mushrooms are a rich source of varying amounts of protein and fiber and a powerful antioxidant called selenium, which helps to support the immune system and prevent damage to cells and tissues [11-13]. Escalating food chains and food markets in developing countries coupled with ongoing research for untapped uses of mushrooms is also opening new opportunities for the mushroom market in the coming years [14]. Therefore, there is a need for the development of new mushroom cultivation methods that can guarantee an increase in mushroom productivity and quality (nutritional and medicinal properties) [7].

Oyster mushrooms can be cultivated on a wide variety of substrates [15]. The quality of the substrate is the main factor in the success of growing mushrooms as it provides all the energy and nutrients that the mushrooms will use while growing. Agricultural wastes are often used as a substrate material, for instance, cassava stalks, coffee bean husks, coffee pulp, corn cobs, corn stubble, cottonseed cake, pulse husks, rice hulls, sawdust, sugarcane bagasse, tea leaves, tobacco stalks, wheat straw, and water hyacinth. In many parts of Zimbabwe, wheat straw, bush grass, and horse manure are commonly used with supplements of chicken manure, cottonseed meal, and sunflower seed cake, amongst others [16]. Biochar was also recently reported as a promising mushroom substrate material (i.e., applying microwave vacuum pyrolysis to design moisture retention and $\mathrm{pH}$ neutralizing palm kernel shell biochar for mushroom production [17], microwave vacuum pyrolysis conversion of waste mushroom substrate into biochar for use as a growth medium in mushroom cultivation [18], production of biofertilizer from microwave vacuum pyrolysis of palm kernel shell for the cultivation of oyster mushroom [19]). In addition to these locally available materials, baobab waste can also be used as a substrate for oyster mushroom production.

The materials on which oyster mushrooms can be grown are locally available and cheaply accessed, resulting in low costs in the growing of oyster mushrooms. In most urban areas, especially in sub-Saharan Africa, half of the solid waste generated is not collected and is rarely recycled but thrown in dumpsites, thus posing serious health and environmental impacts [20]. However, in some drought-stricken areas where there is very little annual rain, smallholder farmers may not be able to harvest enough so that they can use the agricultural wastes for growing mushrooms. Furthermore, almost all agricultural wastes have alternative uses and this may pose a challenge on the material on which to grow oyster mushroom. This is because some or all of the materials such as maze residues and wheat straw, which have been found to be high yielding, are used for several other functions such as feeding animals.

Research has been done on the baobab fruit shell to measure the lignin, cellulose, hemicelluloses, volatile matter, carbon content, and nitrogen content. Baobab fruit shells have been found to contain lignin (54.08\%), cellulose (24.87\%), and hemicellulose $(21.05 \%)$ content, as well as proximate analysis such as ash content (5.17\%), moisture content $(6.48 \%)$, volatile matter $(86.73 \%)$, and carbon content (1.22\%) [21]. This assessment plays a vital role in exploring the potential benefits of utilizing baobab fruit shells in the cultivation of oyster mushroom as it contains more nutritional requirements of oyster than some substrates which are currently being used by mushroom growers. This study, therefore, seeks to establish the suitability of baobab residues for use as a substrate in the cultivation of organic oyster mushroom with the anticipation of adding baobab fruit shells to the already existing list of substrates for mushroom growers and also provide a cheap, locally available, organic, and high yielding substrate.

\section{Materials and Methods}

2.1. Description of Experimental Sites and Details. The study on the evaluation of baobab as a potential substrate for oyster mushroom production was conducted in Christon Bank, located in Mazowe, Zimbabwe.

Baobab fruit shell $\left(\operatorname{Trt}_{1}\right)$ was compared to the three base substrates [wheat straw $\left(\operatorname{Trt}_{2}\right)$, sawdust substrates $\left(\mathrm{Trt}_{3}\right)$, and maize cobs $\left.\left(\operatorname{Trt}_{4}\right)\right]$ of $1 \mathrm{~kg}$ dry weight and assessed for its potential to produce oyster mushrooms. A randomized complete design was used with 10 replicates. Substrates were ground into small units of about $2 \mathrm{~cm}$ lengths and weighed. The weighed substrates were then soaked in water for 24 hours, washed, and drained out. The substrates were tightly packed into clear plastic fruiting bags of $14 \mathrm{~cm}$ diameter and $30 \mathrm{~cm}$ length. Spawning was done using a triple spawning procedure where inoculation was at one-third of the substrate height of the bag, two-thirds of the bag, and at the third top of the bag (Figure 1(a)). About 80 grams of spawn was used per bag. The spawned substrates were kept in a dark incubation room until the spawn run was complete (Figure 1(b)). After the spawn run was complete, the mushroom bags were punched to create holes through which the mushroom grows out of the bags (Figure 2(a)) and then the fruiting bags were taken to the fruiting house (Figure 2(b)).

The duration of developmental stages, mycelium vigor, biological efficiency of the oyster mushroom, and yields were 

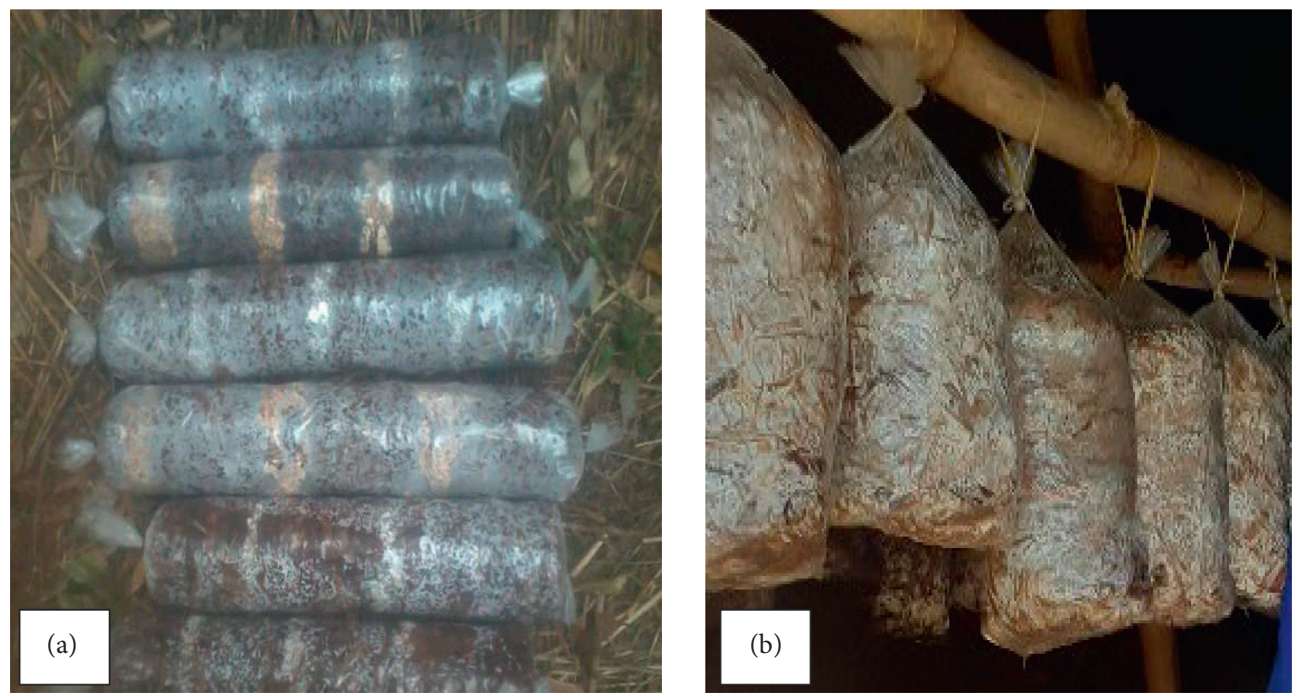

Figure 1: Pictures showing the bags soon after spawning and after full spawn run, respectively (from left to right).
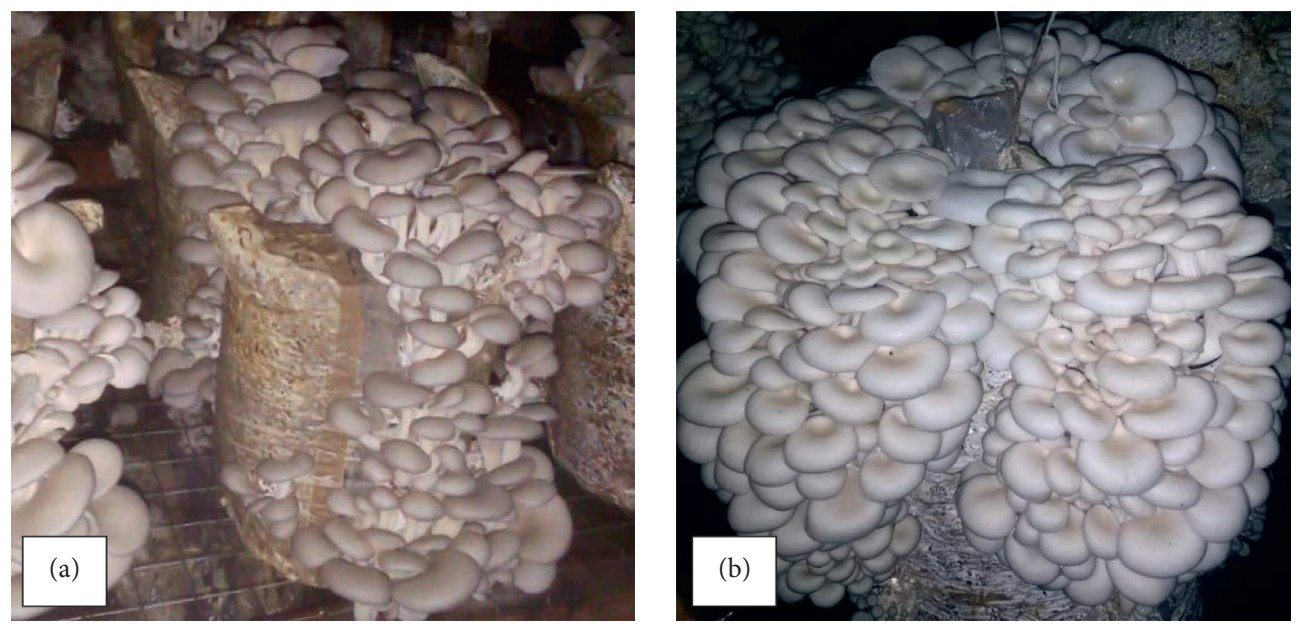

FIGURE 2: Pictures showing mushroom sprouting out of baobab fruit shells bag.

determined by recording the following. Days from spawning to full spawn run, days taken from $100 \%$ spawn run to pinhead formation, days taken from spawning to pinhead formation, days taken to first harvest, days are taken from spawning to first marketable harvest, fresh yield per flush, effectiveness of a mushroom strain and substrate combination when growing mushrooms (biological efficiency) was measured for all the substrates.

$$
\mathrm{BE}=\left(\frac{\text { weight of harvest }}{\text { weight of dry substrate }}\right) \times 100 \text {. }
$$

2.2. Statistical Analysis. Data collected were tested for normality before being subjected to analysis of variance (ANOVA) using Minitab 16 statistical package. For significant differences between the substrates, separation of means was done using Fisher's multiple range test at $\alpha=0.05$ level of significance.

\section{Results and Discussion}

3.1. Days from Spawning to Full Spawn. Results on the influence of the type of substrate on the number of days taken from spawning to full spawn run are shown in Table 1. Results review that there was a significant $(p<0.05)$ difference in the number of days taken from spawning to full spawn run by the baobab fruit shells, wheat straw, sawdust, and the maize stover. Overly the period from spawning to full spawn run ranged from 21 to 33 days, with $\operatorname{Trt}_{2}$ and $\operatorname{Trt}_{1}$ taking the least amount of time, 22.8 and 25.8 days, respectively. Treatment $\mathrm{Trt}_{4}$ took more days (29.5) to reach a full spawn run than all the other substrates. The mean number of days from spawning to full spawn run recorded was 26.4 . 
TABLe 1: Number of days taken for the developmental stages in baobab fruits shells, wheat straw, sawdust, and maize cobs.

\begin{tabular}{|c|c|c|c|c|c|}
\hline \multirow{2}{*}{ Treatment } & \multicolumn{5}{|c|}{ Variables } \\
\hline & S-FSR & FSR-PHF & S-PHF & S-FH & $\mathrm{S}-\mathrm{FMH}$ \\
\hline $\mathrm{Trt}_{1}$ & $25.8^{\mathrm{ab}}$ & $14.4^{\mathrm{a}}$ & $39.4^{\mathrm{a}}$ & $47.4^{\mathrm{a}}$ & $49.7^{\mathrm{a}}$ \\
\hline $\mathrm{Trt}_{2}$ & $22.8^{\mathrm{b}}$ & $7.4^{\mathrm{b}}$ & $30.1^{\mathrm{b}}$ & $31.3^{\mathrm{c}}$ & $31.4^{\mathrm{c}}$ \\
\hline $\mathrm{Trt}_{3}$ & $27.2^{\mathrm{a}}$ & $9.4^{\mathrm{b}}$ & $36.7^{\mathrm{a}}$ & $37.8^{\mathrm{b}}$ & $37.8^{\mathrm{b}}$ \\
\hline $\mathrm{Trt}_{4}$ & $29.5^{\mathrm{a}}$ & $10.5^{\mathrm{ab}}$ & $39.5^{\mathrm{a}}$ & $41.4^{\mathrm{b}}$ & $41.1^{\mathrm{ab}}$ \\
\hline Mean & 26.4 & 10.4 & 36.4 & 39.5 & 40.0 \\
\hline Significance & $* * *$ & $* * *$ & $* * *$ & $* * *$ & $* * *$ \\
\hline CV\% & 13.9 & 32.4 & 14.5 & 19.1 & 18.1 \\
\hline
\end{tabular}

*** Significant at $p<0.05$. Within the columns, means followed by the same superscript letters are not significantly different, LSD0.05. S-FSR: days from spawning to full spawn run. FSR-PHF: days from full spawn run to pinhead formation. S-PHF: days from spawning to pinhead formation. S-FH: days to the first harvest. S-FMH: days from spawning to first marketable harvest.

\subsection{Days from Full Spawn Run to First Pinhead Formation.} Figures regarding the time taken from full spawn run to the first pinhead formation shown in Table 1 indicate that there were statistical $(p<0.05)$ differences among the different substrates. The number of days recorded from $\operatorname{Trt}_{2}$ (7.4) and $\mathrm{Trt}_{3}$ (9.4) was below the average of the days from full span run to pinhead formation for all the treatments. The highest number of days was recorded from $\operatorname{Trt}_{1}$ (14.4). The mean number of days from full spawn run to pinhead formation recorded was 10.4 .

3.3. Days from Spawning to First Pinhead Formation. Data for days taken from spawning to the first pinhead formation are shown in Table 1. Days from spawning to first pinhead formation differed statistically $(p<0.05)$ between treatments with the least number of days (32.1) recorded from Trt2 while Trt4 recorded numerically the highest number of days (39.5). However, the mean number of days from spawning to first pinhead formation was not significant ( $p>0.05)$ between Trt1 (39.4), Trt3 (36.7), and Trt4 (39.5). The mean number of days from spawning to the first pinhead formation recorded was 36.4 .

3.4. Days from Spawning to First Harvest. Table 1 indicates that the recorded data was significant $(p<0.05)$ for the number of days from spawning to the first harvesting of the mushrooms. Trt1 recorded significantly $(p<0.05)$ the highest number of days (47.4) to first harvesting from the time of spawning. Trt 2 and Trt 3 registered means that were below the average of all the treatments in the study. However, the mean number of days for Trt3 (37.83) was not significantly $(p>0.05)$ different from Trt4 (41.4). The number of days recorded from spawning to the first harvest ranged from 30 to 50 days. The mean number of days from spawning to first harvest recorded was 39.5.

\subsection{Days from Spawning to the First Marketable Harvest.} Data on the number of days taken to reach the first marketable harvest from spawning is presented in Table 1. Presented data show that the means for $\mathrm{Trt}_{2}$ and $\mathrm{Trt}_{3}$ were below the average for the treatments in the study, suggesting it took fewer days to reach the first marketable harvest. Trt ${ }_{1}$ recorded the highest mean for the number of days and it did not differ $(p>0.05)$ with the mean for $\operatorname{Trt}_{4}(41.1)$; however, $\mathrm{Trt}_{2}$ had the least number of days (31.41) recorded in this study. The average number of days from spawning to the first marketable harvest recorded was 40.0.

3.6. Biological Yield. Data pertaining to the influence of the substrate on the biological yield of mushrooms is shown in Figure 3 . There were statistically significant $(p<0.05)$ differences in the biological yield across all the different substrates investigated. The highest fresh weight (682 g) was recorded from $\mathrm{Trt}_{3}$ followed by $\mathrm{Trt}_{2}$ with a weight of $594 \mathrm{~g}$. $\mathrm{Trt}_{1}$ and $\mathrm{Trt}_{4}$ registered yields below the average for all the treatments with $\mathrm{Trt}_{1}$ registering the least fresh weight (482 g) in this investigation. The average biological yield for all the treatments recorded was $569 \mathrm{~g}$.

3.7. Biological Efficiency (BE). Data in Figure 4 review that the contribution percentages of each of the first three harvest flushes differed $(p<0.05)$ between the substrate treatments. The biological efficiency (BE) of the first harvest flush did not differ strongly between substrate treatments. $\mathrm{Trt}_{4}$ registered the least percentage (22.2\%) contribution while the means for $\mathrm{Trt}_{1}, \mathrm{Trt}_{2}$, and $\mathrm{Trt}_{3}$ were not significant $(p>0.05)$ from each other. $\operatorname{Trt}_{3}$ had the highest $(24.3 \%)$ biological efficiency (BE) for the second harvest flush, while $\operatorname{Trt}_{1}$ had the least (9.6\%). The third harvest flush saw $\operatorname{Trt}_{1}$ registering the lowest biological efficiency (BE) contribution to the final yield of mushrooms among all the substrate treatments. It is observed that the biological efficiency (BE) was decreasing from the first to the third harvest flushes for all the substrate treatments in the investigation. Within the first two harvest flushes, $\mathrm{Trt}_{3}$ gave the highest yield $(605 \mathrm{~g})$ while the least yield (402 g) was from $\mathrm{Trt}_{4}$.

\section{Discussion}

An analysis of yield attributing factors and yield of mushroom was obtained from the different substrates investigated in this study. The different substrates investigated in this study showed the varying time to full spawn run, days to pinhead formation, days to the first harvest, days to marketable harvest, and total harvest relative to baobab fruit shells. 


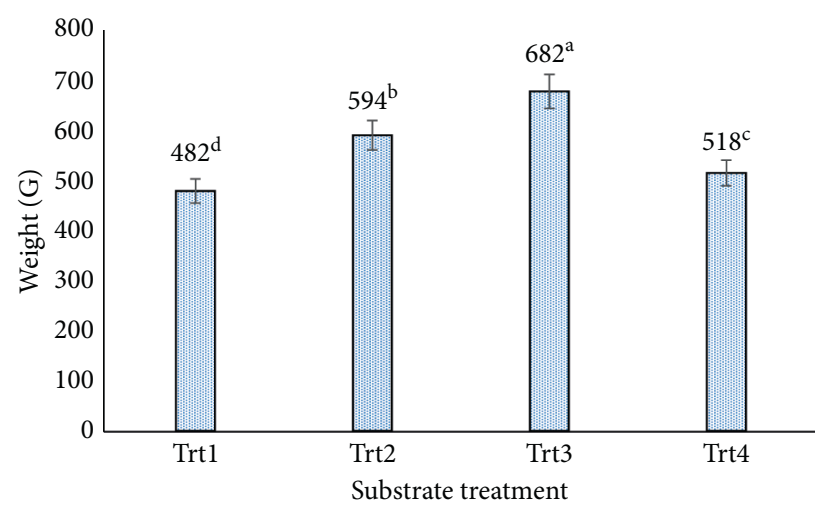

Figure 3: Biological yield as affected by substrate treatment. Means with different letters are significantly different at $p<0.05$. Trt ${ }_{1}=$ baobab fruit shells, $\operatorname{Trt}_{2}=$ wheat straw, $\operatorname{Trt}_{3}=$ sawdust, and $\operatorname{Trt}_{4}=$ maize cobs.

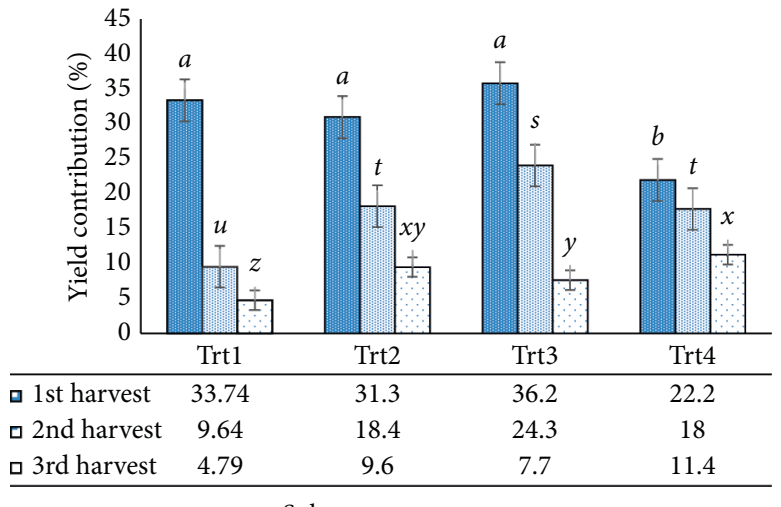

Substrate treatment

FIGURE 4: Contribution to biological yield of the first three harvest flushes of the mushroom as affected by substrate treatment. Columns with

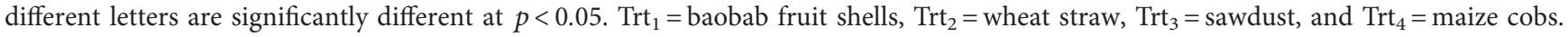

The time taken for spawn run completion in the various substrates compares well with the findings of [22], which reported a period of 12 to 30 days to full spawn run in $P$. ostreatus. It is established that the mycelium running rate of oyster mushroom is a function of the different media materials. The shorter time taken for spawn run indicates that baobab fruit shells consist of higher carbon to nitrogen ratio $(\mathrm{C} / \mathrm{N})$ which is favorable for a higher and faster mycelial growth rate. However, mushroom pinning requires conditions that are different from those required for mycelial growth [23]. The pinheads first occurred around 30 days after spawning in the baobab fruit shells substrate, which compares well with Bhatti et al. [24], who used a $70 \mathrm{~g}$ spawn rate per $\mathrm{kg}$ on a substrate dry weight basis. This is, however, in contrary to Buah et al. [25] who recorded the highest number of days to first pinhead formation of 24 days using sawdust and grounded corn cob. Baobab fruit shells showed a statistically significant difference in the days taken to first pinhead formation, but results show that it lies in the range of some of the commonly used substrates such as wheat, as recorded by [26]. The differences in the time taken to pinhead formation may be attributed to the different levels in carbon and nitrogen of the substrates. The ease of use of the carbon and nitrogen from the lignocellulose materials of the different substrates directly contribute to the formation of the pinheads.

The first three flushes have the highest contribution to the total biological yield and hence they are the most important [27]. The baobab fruit shells had a higher first flush yield as compared to the other substrates such as wheat straw and maize cobs. The yield in this experiment was measured from the first three flushes, which are usually the highest yielding. If a substrate is low in nitrogen (less than $0.8 \%$ ), at fructification, when there is a huge demand for nitrogen needed for the growth of mycelium, nitrogen becomes insufficient and restricts mushroom growth and yield. The highest biological yield was recorded on sawdust. The wheat straw, maize cobs, and baobab fruit shells were not significantly different statistically $(p>0.05)$. This shows baobab fruit shells can be equally used as the other substrates (wheat straw and maize cobs) since, in this experiment, it produced a similar yield.

The higher yield performance obtained from the sawdust, wheat straw, and maize cobs substrates in comparison to the baobab fruit shells may be attributed to the easiness of availing sugars for growth from these cellulosic substrate materials. Biological efficiency (BE) is used as a measure of substrate conversion into mushroom [28]. The substrate 
materials provide a reservoir of lignin, hemicelluloses, and cellulose which is utilized by the mushroom for growth and fructification. For the first flush, the easiness of the degradation of the cellulosic substrate materials to provide sugars and assimilable nitrogen for growth was lowest from the maize cobs, thus a lower biological efficiency (BE) compared to baobab, wheat straw, and sawdust substrates. Similar to this study, Islam et al. [29] and Buah et al. [25] reported that sawdust was consistently the best substrate to support mycelia growth and fruiting body formation, and it was not significantly different from baobab fruit shells. The yield decreased with succeeding flushes as the nutrients for growth and development depreciate due to exhaustion of the substrate from which the $P$. ostreatus spp feeds.

\section{Conclusion and Recommendations}

The results from the experiment show that baobab fruit shells can be used in the cultivation of oyster mushroom as there was no statistically significant difference in yield per fresh weight basis compared with the other substrates such as maize cobs and wheat straw. The fresh yield and biological efficiency are correlated to the strain, nutrition of the substrate, and the growth conditions that the mushroom is exposed to. Utilization of practices that aid in the optimization of nutrients for the growth of mushrooms could help improve the efficiency of the mushroom strain and substrate [2].

Supplementation of the baobab fruit shells with cheap organic substrates could, however, aid in improving the productivity of the substrate. Previous researches that were done in $[30,31]$ showed that sunflower seed cake, cereal meals, brans, chicken manure, cotton seed meal, pigeon pea hulls, and wheat straw are some of the cheap and easily accessible agricultural waste materials which can be successfully utilized as supplements in oyster mushroom production.

5.1. Further Research Study. Although crushed baobab fruit shells can be used solely in mushroom cultivation, there is a need for further studies to find the most productive and costeffective supplements which can be used so that they can be recommended to mushroom growers. Research still needs to be done on the other substrates and explore ways in which they could be improved in terms of productivity and efficiency.

\section{Data Availability}

The raw data used to support the findings of this study are available from the corresponding author upon request.

\section{Conflicts of Interest}

The authors declare that they have no conflicts of interest.

\section{References}

[1] D. Dubey, B. Dhakal, K Dhami et al., "Comparative study on effect of different substrates on yield performance of oyster mushroom," GJBAHS, vol. 7, 2019.
[2] P. Stamets, Growing Gourmet and Medicinal Mushrooms, p. 150, TenSpeed Press, Berkeley, CA, USA, 2000.

[3] D. J. Royse, "A global perspective on the high five: agaricus, pleurotus, lentinula, auricularia \& flammulina," in Proceedings of the 8th International Conference on Mushroom Biology and Mushroom Products, New Delhi, India, November 2014.

[4] A. S. Sekan, O. S. Myronycheva, O. Karlsson et al., "Green potential of Pleurotus spp. in biotechnology," PeerJ, vol. 7, Article ID e6664, 2019.

[5] S. Trudell and J. Ammirati, Mushrooms of the Pacific Northwest, Vol. 134, Timber Press Field Guides, Portland, Oregon, 2009.

[6] M. A. Khan, M. Tania, R. Liu, and M. M. Rahman, "Hericium erinaceus: an edible mushroom with medicinal values," Journal of Complementary and Integrative Medicine, vol. 10, no. 1, 2013.

[7] W. A. Wan Mahari, W. Peng, W. L. Nam et al., "A review on valorization of oyster mushroom and waste generated in the mushroom cultivation industry," Journal of Hazardous Materials, vol. 400, Article ID 123156, 2020a.

[8] P. G. Miles and S. T. Chang, Mushrooms: Cultivation, Nutritional Value, Medicinal Effect, and Environmental Impact, CRC Press, Boca Raton, FL, USA, 2014.

[9] A. W. Bilal, H. B. R, and H. W. A, "Nutritional and medicinal importance of mushrooms," Journal of Medicinal Plants Research, vol. 4, no. 24, pp. 2598-2604, 2010.

[10] S. A. Heleno, L. Barros, M. J. Sousa, A. Martins, and I. C. F. R. Ferreira, "Tocopherols composition of Portuguese wild mushrooms with antioxidant capacity," Food Chemistry, vol. 119, no. 4, pp. 1443-1450, 2010.

[11] M. D. Kalaras, J. P. Richie, A. Calcagnotto, and R. B. Beelman, "Mushrooms: a rich source of the antioxidants ergothioneine and glutathione," Food Chemistry, vol. 233, p. 429, 2017.

[12] M. Kozarski, A. Klaus, M. Niksic, G. van, M. Vrvic, and D. Jakovljevic, "Polysaccharides of higher fungi: biological role, structure, and antioxidative activity," Chemical Industry, vol. 68, no. 3, pp. 305-320, 2014.

[13] S. Khatua, S. Paul, and K. Acharya, "Mushroom as the potential source of new generation of antioxidant: a review," Research Journal of Pharmacy and Technology, vol. 6, pp. 496-505, 2013.

[14] R. H. Peterson, K. W. Hughes, and N. Psurtseva, "Biological Species in Pleurotus". Archived from the Original on 2015-0302, 2015.

[15] W. Ngezimana, T. A. Mtaita, and I. Mtukwa, "Potential of organic residues in producing oyster mushroom," Pleurotus Ostreatus Fr. (Polyporaceae) International Journal of Biological and Chememical Sciences, vol. 1, no. 2, pp. 108-120, 2007.

[16] W. Ngezimana, T. A. Mtaita, M. Shoko, and M. Tagwira, "Improving biological efficiency of Oyster mushroom, Pleurotus ostreatus Fr.(Polyporaceae), through composting and use of organic supplements," International Journal of Biological and Chemical Sciences, vol. 2, no. 1, pp. 72-80, 2008.

[17] W. A. Wan Mahari, W. L. Nam, C. Sonne et al., "Applying microwave vacuum pyrolysis to design moisture retention and $\mathrm{pH}$ neutralizing palm kernel shell biochar for mushroom production," Bioresource Technology, vol. 312, Article ID 123572, 2020b.

[18] S. S. Lam, X. Y. Lee, W. L. Nam et al., "Microwave vacuum pyrolysis conversion of waste mushroom substrate into biochar for use as growth medium in mushroom cultivation," Journal of Chemical Technology \& Biotechnology, vol. 94, no. 5, pp. 1406-1415, 2019. 
[19] W. L. Nam, X. Y. Phang, M. H. Su et al., "Production of biofertilizer from microwave vacuum pyrolysis of palm kernel shell for cultivation of Oyster mushroom (Pleurotus ostreatus)," Science of the Total Environment, vol. 624, pp. 9-16, 2018.

[20] P. N. Mafume, W. Zendera, M. Mutetwa, and N. Musimbo, "Challenges of solid waste management in Zimbabwe: a case study of Sakubva high density suburb," Journal of Environment and Waste Management, vol. 3, no. 2, pp. 142-155, 2016.

[21] N. A. Kabbashi, M. E. S. Mirghani, M. Z. Alam, and I. Adebayo Bello, "Characterization of the Baobab fruit shells as adsorption material," International Food Research Journal, vol. 24, pp. S472-S474, 2017.

[22] H. Prasad, R. Dhakal, D. C. Geetesh, and D. Kalauni, "Effect of various substrates on growth and yield performance of oyster mushroom (Pleurotus ostreatus) in chitwan, Nepal," International Journal of Applied Sciences and Biotechnology, vol. 6, p. 215, 2018.

[23] F. Patrick, G. Y. S. Mtui, A. M. Mshandete, and A. K. Kivaisi, "Ligninolytic enzymes activities of Pleurotus Sapidus P969 during vegetative growth and fruit development on sugarcane residuesbased substrates," International Journal of Biotechnology, vol. 4, no. 3, pp. 58-71, 2014.

[24] M. I. Bhatti, M. Jiskani, K. Wagan, M. Pathan, and A. Magsi, "Growth, development and yield of oyster mushroom, Pleurotus ostreatus (Jacq. Ex. Fr.) Kummer as affected by different spawn rates," Pakistan Journal of Botany, vol. 39, no. 7, pp. 2685-2692, 2007.

[25] J. N. Buah, G. C. Van der Pu, E. A. Bediako, E. A. Abole, and F. Showemimo, "The growth and yield performance of oyster mushroom (Pleurotus ostreatus) on different substrates," Biotechnology (Faisalabad), vol. 9, no. 3, pp. 338-342, 2010.

[26] M. I. Bhatti, M. M. Jiskani, K. H. Wagan, M. A. Pathan, and M. R. Magsi, "Growth development and yield of oyster mushroom Pleurotus ostreatus (JACQ.EX.FR) Kummer as affected by different spawn rates Pak," American Journal of Botany, vol. 39, pp. 2685-2692, 2007.

[27] D. T. Zireva, M. Fanadzo, and A. B. Mashingaid, "Effect of substrate quantity and shelf position on yield of oyster mushroom (pleurotus sajor caju)," Pakistan Journal of Biological Sciences, vol. 10, no. 19, p. 3458, 2007.

[28] T. O. Oseni, S. S. Dube, P. K. Wahome, M. T. Masarirambi, and D. Earnshaw, "Effect of wheat bran supplement on growth and yield of oyster mushroom (Pleurotus ostreatus) on fermented pine sawdust substrate," Experimental Agriculture \& Horticulture, vol. 30, p. 40, 2012.

[29] M. Z. Islam, M. H. Rahman, and F. Hafiz, "Cultivation of oyster mushroom (Pleurotus flabellatus) on different substrates," International Journal of Sustainable Crop Production, vol. 4, pp. 45-48, 2009.

[30] J. Carrasco, D. C. Zied, J. E. Pardo, G. M. Preston, and A. Pardo-Giménez, "Supplementation in mushroom crops and its impact on yield and quality," $A M B$ Express, vol. 8, no. 1, pp. 146-156, 2018.

[31] J. Ashraf, M. Ali, W. Ahmad, C. Ayyub, and J. Shafi, "Effect of different substrate supplements on oyster mushroom," (Pleurotus spp.) Production, vol. 1, pp. 44-51, 2013. 